\title{
GIFTED AND REGULAR LEARNERS AND THEIR FOREIGN LANGUAGE STRATEGY USE
}

\author{
Bozena Horvathova - Eva Reid
}

doi: 10.18355/PG.2016.5.2.403-423

\begin{abstract}
The paper provides an insight into the use of foreign language strategies of pupils with general intellectual giftedness and pupils in traditional classes. There is quite a unique form of educating gifted children in Slovakia, which provides primary and lower secondary education in segregated special classes. Teaching English as a foreign language to gifted children has its specifics, which are briefly discussed. The main focus of this paper is the analyses of foreign language strategies use of gifted pupils and regular pupils in traditional classes at primary education. Young learners' language strategies use survey was used and it is based on communicative skills, which include the receptive skills of listening and reading, the productive skills of speaking and writing, and also strategies that cut across all four skill areas, such as vocabulary and translation strategies.
\end{abstract}

\section{Key words}

gifted learners, traditional classes, foreign language learning strategies

\section{Notion of General Intellectual Giftedness}

There are many theories on the origin of giftedness, whether it is a matter of nature or nurture. The nature supporters believe that native abilities and heritability account for as much as $80 \%$ of intelligence. They claim that genetics play an important role in giftedness, but it is not immune against experience, which can influence the development of the gifted (Gottfredson, 2011). The supporters of nurture claim that main key to success is effort, which can be influenced by intelligence.

According to Gagné (1985: 104) "giftedness designates the possession and use of untrained and spontaneously expressed superior natural abilities (called aptitudes or gifts) in at least one ability domain, to a degree that places an individual at least among the top 10\% of his or her age peers." Natural abilities include intellectual, creative, socioaffective and sensorimotor gifts. These gifts can be easier observed in young children because they have not been influenced much by environment and schooling.

In Slovakia, Laznibatova $(2007,2012)$ defines giftedness as an exceptional general intellectual ability. Gifted individuals' high potentials can be identified by reliable diagnostic methods. Gifted children exhibit high level of general intellectual abilities, IQ higher than 130, specific academic predispositions and creative thinking. Gifted children represent the top ten per cent of population, where genetic predispositions together with easy approach, natural behaviour and speed of learning are important factors. Laznibatova (ibid.) adds that every gifted individual is unique and the 
population of the gifted does not form a homogenous group. Gifted individuals are a diverse group with various foundations and conditions for development. This diversity influences the process of development, which emerges in various levels and areas of giftedness.

Silverman (2012) views giftedness as a psychological reality, which can be observed in young children and documented on measures of general intelligence. Characteristics such as abstract thought, excellent memory, good reasoning, fast learning, creative imagination, insightfulness, compassion, perfectionism, intensity, curiosity, long attention span, etc. can be recognized as common traits of gifted children. Also one of the most influential scholars on giftedness, Renzulli (1977) believed that intellect is the fundamental feature of giftedness.

The best known and most popular IQ test is the Stanford-Binet Intelligence Scale test. It measures five factors of cognitive ability: fluid reasoning, knowledge, quantitative reasoning, visual-spatial processing and working memory (Laznibatova, 2007). Today, there are various kinds of IQ tests including visual, verbal (based on abstract reasoning problems), vocabulary, arithmetic, general knowledge, etc. items. Many gifted education programs around the world set as a minimum criterion an IQ score of 130 for recognizing children as gifted.

Development of cognitive and meta-cognitive processes should be one of the most important features of gifted education. Meta-cognition is in fact knowing own cognitive capacity. It influences self-regulation and that has an effect on learning processes. Achieving management of thinking is a feature proving intellectual development. Meta-cognition can be also understood as intrapersonal intelligence (Duchovicova, 2007, 2009, 2010). Fisher (2004) believes that meta-cognition is the most important feature of intelligence, because it influences other forms of intelligence (logicmathematical, verbal, special, physical, musical, interpersonal).

Some of the best indicators of identification of gifted children are high language abilities of small children. They can speak fluently in their native language in a very early age and they show interest in listening to texts, repeating what has been read, correcting or completing texts (Johnsen, 2011). Gifted children can often read before entering primary school.

Foreign language learning abilities are a specific part of language giftedness. Language giftedness is represented by differentiation and imitation of language phonemes, ability to remember foreign words and phrases, differentiate morphological specifications, generalize grammatical and lexical specifications of a particular language (Duchovicova, 2007, 2009, 2010). However, there are different opinions on special foreign language abilities - some scholars believe that they are dependent on intelligence; some claim that language abilities are independent or even non-existent. Teaching foreign languages supporting higher cognitive abilities is studied by Klimova (2015), who is implementing smart technologies, Vesela (2010), who is developing foreign languages through creative writing and suggests special group and individual activities for gifted learners. 
In Slovakia, there is quite a unique system of educating children with general intellectual giftedness. Pupils are either integrated in regular classes or they are educated in segregated special classes. Segregated education has been in existence for more than 20 years. Nowsadays, there are 28 schools in Slovakia that offer segregated education for gifted children (Laznibatova, 1996, 1998, 2001, 2008; Dockal 2005). A School act 245/2008 § 2 letter j) and q) specifies gifted children (pupils) as children with specific educational needs. Children with special educational needs have to be identified by centres of pedagogical-psychological advisory services. Apart from the minimum requirements set in the national curriculum, there are certain modifications concerning the contents (enriching, additional and widening contents, additional books, elaboration of projects, etc.) (VÚDPaP, 2009). There are two foreign languages recommended in gifted education in Slovakia. English is the first foreign language taught from the first grade of primary school. There are not any specific recommendations in the curriculum concerning teaching foreign languages to gifted children. Based on research done by Reid (2014) pupils quickly lose interest when traditional approach is used. Pupils enjoyed demanding activities requiring logical thinking, deduction, counting and quick responses. With the issue of foreign language teaching and plurilingualism in special needs education can be found in publications by Bírová (2013) and Kovacikova (2015).

With this research we tried to find out and analyse which foreign language strategies gifted primary school pupils use when learning English in comparison to learners in traditional classes.

\section{Language Learning Strategies and Variables Affecting Language Learning Strategies}

One of the best known definitions of learning strategies was formulated by Oxford (1990: 8) who states that "learning strategies are specific actions taken by the learner to make learning easier, faster, more enjoyable, more self-directed, more effective, and more transferable to new situations". According to O'Malley and Chamot (1990: 78-9) "language learning strategies are applied by language learners as a means to acquire and to use information that learners have acquired, stored or recalled, and can also promote autonomous learning". The more recent definition of the term learning strategy asserts that "learning strategies are targeted cognitive operations aimed at preserving the cognition and are potentially conscious and controlled activities, which should help learners to manage a learning task” (Hasselhorn \& Labuhn, 2010: 73).

An important part of the descriptive research on language learner strategies has been the linking of self-reported strategy use with factors which influence learners using language learning strategies. Language learners use specific strategies depending on their age, sex, attitude, aptitude, learning stage, task requirements, teacher expectation, learning styles, individual differences, motivation, cultural differences, beliefs about language learning, and language proficiency, etc. (Rubin, 1975; Bialystok, 1979; Abraham \& Vann, 1987; Oxford, 1989; Oxford \& Nyikos 1989; Chamot \& Kupper 1989; Ehrman and Oxford, 1995; Horvathova 2013a, 2013b). 
However, we have not come across any research which would focus on examining the relationship between the language learning strategy use and gifted children. Only Rubin (1975) focused on observation of "successful language learners", and concluded that the characteristics of good language learners are: to be a willing and accurate guesser, to have a strong drive to communicate, to learn from communication, to be uninhibited and willing to make mistakes, to pay attention to form by looking for patterns, to take advantage of every opportunity to practise, to monitor the speech of themselves and others, and to focus on meaning. Based on this notion we have decided to find out more about the foreign language strategy use of gifted learners in comparison to learners in regular classes.

\section{Classification of Language Learning Strategies}

For the purpose of this study a classification of language learning strategies is important as a starting point for the analysis procedure. Almost two dozen strategy classification systems have been established respecting different criteria. According to Cohen and Weaver (2005) three primary and several secondary classification schemes, which have overlapping character, can be applied to language learning strategies. Mainly, the primary strategy schemes (goal-based, skills-based and function-based) can help both teachers and learners understand the support roles of language learning strategies. To make the overview of the used strategies transparent, only two primary classification schemes of strategies are reflected in this article: skills-based and function-based one.

\section{Classifying Strategies by Language Skills and Language Systems}

According to Cohen and Weaver (2005: 33-37) and CEFR (2011: 63-87) strategies can be classified by skill area, which includes the receptive skills of listening and reading and the productive skills of speaking and writing. Receptive strategies - aural reception (listening) and visual reception (reading) - involve identifying the context and knowledge of the world relevant to it, activating in the process what are thought to be appropriate schemata. Productive strategies - oral production (speaking) and written production (writing) - involve mobilising resources, balancing between different competences, exploiting strengths and underplaying weaknesses in order to match the available potential to the nature of the task.

There are also language system strategies that cut across all four skill areas, such as vocabulary or grammar learning. Learners need to learn new words or new grammar structures to be able to understand them when they hear them, while others are needed for speaking or writing.

\section{Classifying Strategies by Function}

Oxford (1990) states that strategies can be classified into six functional groups: cognitive, metacognitive, memory, compensation, affective and social strategies. These six broad strategies include nineteen strategy sets with a further sixty-two specific strategies. 
Cognitive strategies cover many of the processes or mental manipulations that learners go through in both learning the target language (e.g., identification, grouping, retention, and storage of language material) and in using it (e.g., retrieval of language material, rehearsal, and comprehension or production of words, phrases, and other elements of the target language). Repetition, resourcing, translation, grouping, note taking, deduction, recombination, imagery, auditory representation, key word, contextualization, elaboration, transfer, inferencing are among the most important cognitive strategies (Chamot 1987; Oxford 1990).

Metacognitive strategies allow learners to control their language learning by planning what they will do, checking how it is going, and then evaluating their performance on a given task. Advance organizers, directed attention, selective attention, self-management, functional planning, selfmonitoring, delayed production, self-evaluation are among the most important metacognitive strategies. (ibid.)

Memory strategies help language learners to store verbal material and retrieve it when needed for communication Oxford (1990).

Compensation strategies enable the learners to use the new language despite limitation in knowledge. They are intended to make up for an inadequate repertoire of grammar and vocabulary Oxford (ibid). The last two groups - affective and social strategies - are described briefly, but they are not considered in the following analysis.

Affective strategies help students regulate their emotions, motivation, and attitudes and are often used to reduce anxiety and provide selfencouragement. The most common affective strategies are: lowering your anxiety, encouraging yourself, taking your emotional temperature (Chamot 1987; Oxford 1990).

Social strategies involve learners' choices to interact with other learners and native speakers, such as asking questions to clarify social roles and relationships, asking for an explanation or verification, cooperating with others in order to complete tasks and empathising with others (ibid.).

\section{Methodology of the Research}

Data for the study were gathered through the standardised quantitative instrument. The survey was conducted by using a self-reporting measure - a strategy inventory which represents typical example of ordinal variables. The inventory is structured according to the skills-based approach.

\section{Research Aims}

The small-scale pilot study research focused on foreign language learning strategies use of gifted primary school pupils in comparison to learners in traditional classes. The aim was:

1. to investigate which learning strategies gifted pupils use and which are most frequent.

2. to explore, analyse, understand and compare the use of foreign language learning strategies of gifted pupils' and regular pupils in traditional classes. 


\section{Sampling and Research Subjects}

We opted for a non-probability (convenience) sampling targeted at a particular group. The research conducted for the purposes of this study is small-scale research. The inventory was administered to 26 fourth grade primary school pupils with general intellectual giftedness and to 18 fourth grade primary school pupils in traditional class. The 26 pupils attend special segregated classes for gifted children in Nitra - Slovakia. The researcher was a university lecturer with rich experience in teaching English. She spent six months teaching, assisting and observing the gifted and regular pupils. When filling the inventory, the researcher spent one hour going thoroughly with pupils through the inventory. Participants rated the extent to which the statements in the questionnaire described their actual use of each strategy. All 44 inventories were completed correctly and could be submitted to quantitative processing.

\section{Data Collection Instrument}

Oxford's (1990) classification of language learning strategies lays the fundamentals of the Young Learners' Language Strategy Use Survey. It reflects the age of the learners and is intended for pupils at the end of the primary level. The inventory was designed by Cohen and Oxford (2002) and adjusted to the level appropriate to young learners' cognitive processes. It was published in the book Styles and Strategies Based Instruction. A Teachers' Guide (Cohen and Weaver, 2006). The range is reduced from a four-response category scale to three-response category scale as follows: Mark a plus (+) if the statement really describes you. Mark a check ( ) if the statement is somewhat like you. Write a minus (-) if the statement isn't like you. The inventory also invites the learners to add any other strategies they do to think in the new language, thus making the inventory even more youth learner-friendly. The English version was tested with the learners of the 5th and 6th class in the USA. The size of the sample is not given. The inventory comprises of six sections - Listening strategies, Vocabulary strategies, Speaking strategies, Reading strategies, Writing strategies and Translation strategies which are broken down into seventy five items. The items are divided into groups according to language skills and further subdivided into practice strategies, production strategies, comprehension strategies and compensation strategies. Practice strategies involve strategies related to individual skills which increase learner's exposition to the foreign language. Production strategies enhance the language production and encompass speaking and writing strategies aimed at language production. Comprehension strategies develop the language reception and contain listening and reading strategies directed at language comprehension. Compensation strategies enhance the language use even in cases of insufficient language knowledge.

For the purpose of this study the Slovak translation of the Czech version of the Young Learners' Language Strategy Use Survey was used. It contains sixty four brief items and uses simplified scale of yes-no responses. It

Slavonic Pedagogical Studies Journal, ISSN 1339-866o, Volume 5 Issue 2, September 2016 
represents a reduced variant which respects different conditions for learning a foreign language (e.g. the fact that learners do not have an opportunity to use language in a natural environment or are not in contact with native speakers etc.). The inventory was translated and freely designed by Vlčková and Přikrylová with the permission of the authors and adjusted to the use in the context of Czech schools. It is named Inventory for learners at primary schools. Vlčková and Přikrylová provide the inventory in a handbook Strategie učeni se cizímu jazyku: Dotaznik pro žáky (2011). Its purpose is to detect, what procedures pupils apply when learning a foreign language. The Czech version was standardized and tested with 776 learners of the 4th up to 9th class at 18 primary schools. The Cronbach alpha reliability coefficient of the adapted inventory is 0,88 . When piloting the Czech version of the inventory the redundant items with low reliability were removed and thus the reliability of the inventory was increased.

\section{Data Analysis Procedure}

The respondents 'perceptions of using the foreign learning strategies were inspected using an inventory with closed question items. The data obtained through the research instrument were processed quantitatively and are expressed in percentage.

\section{Research Results}

This section presents the results of the inventory-based survey. The skillsbased and function-based approaches are applied to categorize the used strategies. According to the skills-based approach the presented results are grouped into six wider categories labelled as listening, vocabulary, speaking, reading, writing and translation strategies following the structure of the inventory. According to the function-based approach the items are related to the functions of strategies in the process of learning - memory, cognitive, compensation and metacognitive. For easier understanding, the inventory items are arranged into strategy groups, strategy sets and actual strategies in the following tables. The tables illustrate the percentage of learners`strategy preferences. Those preferences which have reached more than $60 \%$ are considered relevant. The Table 1 shows the overall results of the strategies used by gifted pupils $(\mathrm{G})$ and pupils in traditional class $(\mathrm{T})$ across skills and functions. The Table 2 displays the learners' strategy preferences only according to the function-based approach. The subsequent Tables 3-8 present an overview of the reported learning strategy use according to their functions. 
Table 1 Overall strategy use across functions and skills

\begin{tabular}{|c|c|c|c|c|c|c|c|c|c|c|}
\hline & \multicolumn{2}{|c|}{ 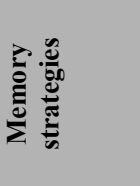 } & \multicolumn{2}{|c|}{ 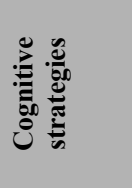 } & \multicolumn{2}{|c|}{ 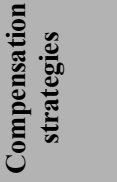 } & \multicolumn{2}{|c|}{ 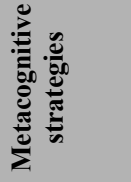 } & \multicolumn{2}{|l|}{ हैं } \\
\hline & G & $\mathbf{T}$ & G & $\mathbf{T}$ & G & $T$ & $\mathbf{G}$ & $\mathbf{T}$ & G & $\mathbf{T}$ \\
\hline $\begin{array}{l}\text { Listening } \\
\text { strategies }\end{array}$ & - & - & 2 & 2 & 3 & 5 & 4 & 2 & 9 & 9 \\
\hline $\begin{array}{l}\text { Vocabulary } \\
\text { strategies }\end{array}$ & 3 & 3 & 1 & 1 & - & - & - & - & 4 & 4 \\
\hline $\begin{array}{l}\text { Speaking } \\
\text { strategies }\end{array}$ & - & - & 3 & 2 & 2 & 4 & 1 & 1 & 6 & 7 \\
\hline $\begin{array}{l}\text { Reading } \\
\text { strategies }\end{array}$ & - & - & 5 & 8 & 1 & 1 & 3 & 3 & 9 & 12 \\
\hline $\begin{array}{l}\text { Writing } \\
\text { strategies }\end{array}$ & - & - & 2 & 3 & 2 & 3 & 1 & 2 & 5 & 8 \\
\hline $\begin{array}{l}\text { Translating } \\
\text { strategies }\end{array}$ & - & - & 3 & 2 & - & - & 1 & - & 4 & 3 \\
\hline Total & $3 / 8$ & $3 / 8$ & $\begin{array}{l}16 / \\
28\end{array}$ & $\begin{array}{l}18 / \\
28\end{array}$ & $\begin{array}{l}8 / \\
16\end{array}$ & $\begin{array}{l}13 / \\
16\end{array}$ & $\begin{array}{l}10 / \\
13\end{array}$ & $\begin{array}{c}8 / 1 \\
3\end{array}$ & $\begin{array}{l}37 / \\
65\end{array}$ & $\begin{array}{l}43 / \\
65\end{array}$ \\
\hline Percentage & $\begin{array}{l}37 \\
\%\end{array}$ & $\begin{array}{l}37 \\
\%\end{array}$ & $\begin{array}{l}57 \\
\%\end{array}$ & $\begin{array}{l}64 \\
\%\end{array}$ & $\begin{array}{l}50 \\
\%\end{array}$ & $\begin{array}{l}81 \\
\%\end{array}$ & $\begin{array}{l}77 \\
\%\end{array}$ & $\begin{array}{l}61 \\
\%\end{array}$ & $\begin{array}{l}57 \\
\%\end{array}$ & $\begin{array}{l}66 \\
\%\end{array}$ \\
\hline
\end{tabular}

According to the function-based approach the strategy use of the gifted learners and learners in regular classes is as follows. Out of eight memory strategies, which are all included in the vocabulary group, three strategies are used actively both by gifted and learners in traditional class. Gifted learners opted for sixteen cognitive strategies out of twenty eight whereas the learners in traditional class use nineteen cognitive strategies. The gifted learners prefer using eight compensation strategies out of sixteen. However, the learners in traditional classes use thirteen compensation strategies which represent the most frequently used strategy group. On the other hand, in the group of gifted learners the highest usage can be seen with the metacognitive strategies where ten out of thirteen are utilized. The learners in traditional class prefer using only eight metacognitive strategies out of thirteen.

Following the skills-based approach, both groups of the learners use the same number of listening and vocabulary strategies. Slight difference can be observed with speaking and translating strategies. More relevant differences are observable with the use of reading and writing strategies where learners in traditional classes utilize three more strategies within each strategy group. 
Table 2 Strategy use according to the function-based approach

\begin{tabular}{|c|c|c|c|c|c|c|c|c|}
\hline \multirow{2}{*}{$\begin{array}{l}\text { Strate } \\
\text { gy } \\
\text { group }\end{array}$} & \multicolumn{2}{|c|}{ Total } & \multirow[t]{2}{*}{ Strategy set } & \multicolumn{2}{|c|}{ Total } & \multirow[t]{2}{*}{ Strategy } & \multicolumn{2}{|c|}{ Total } \\
\hline & G & $\mathbf{T}$ & & $\mathbf{G}$ & $\mathbf{T}$ & & $\mathbf{G}$ & $\mathbf{T}$ \\
\hline \multirow{7}{*}{$\begin{array}{l}\text { Memo } \\
\text { ry } \\
\text { strateg } \\
\text { ies }\end{array}$} & \multirow{7}{*}{$\begin{array}{l}37 \\
\%\end{array}$} & \multirow{7}{*}{$\begin{array}{l}37 \\
\%\end{array}$} & \multirow{3}{*}{$\begin{array}{l}\text { Creating } \\
\text { mental } \\
\text { linkages }\end{array}$} & \multirow{3}{*}{$\begin{array}{l}1 / 3 \\
(33 \\
\%)\end{array}$} & \multirow{3}{*}{$\begin{array}{l}1 / 3 \\
(33 \\
\%)\end{array}$} & Grouping & - & - \\
\hline & & & & & & $\begin{array}{l}\text { Associating, } \\
\text { elaborating }\end{array}$ & 1 & 1 \\
\hline & & & & & & $\begin{array}{l}\text { Placing new words } \\
\text { into a context }\end{array}$ & - & - \\
\hline & & & \multirow{2}{*}{$\begin{array}{l}\text { Applying } \\
\text { images and } \\
\text { sounds }\end{array}$} & \multirow{2}{*}{$\begin{array}{l}1 / 2 \\
(50 \\
\%)\end{array}$} & \multirow{2}{*}{$\begin{array}{l}1 / 2 \\
(50 \\
\%)\end{array}$} & Using imagery & 1 & 1 \\
\hline & & & & & & $\begin{array}{l}\text { Representing sounds } \\
\text { in memory }\end{array}$ & - & - \\
\hline & & & $\begin{array}{l}\text { Reviewing } \\
\text { well }\end{array}$ & $\begin{array}{l}1 / 1 \\
(100 \\
\%)\end{array}$ & $\begin{array}{l}1 / 1 \\
(100 \\
\%)\end{array}$ & Structured reviewing & 1 & 1 \\
\hline & & & $\begin{array}{l}\text { Employing } \\
\text { action }\end{array}$ & $\begin{array}{l}0 / 1 \\
(0 \%)\end{array}$ & $\begin{array}{l}0 / 1 \\
(0 \%)\end{array}$ & $\begin{array}{l}\text { Using mechanical } \\
\text { techniques }\end{array}$ & - & - \\
\hline \multirow{9}{*}{$\begin{array}{l}\text { Cognit } \\
\text { ive } \\
\text { strateg } \\
\text { ies }\end{array}$} & \multirow{5}{*}{$\begin{array}{l}57 \\
\%\end{array}$} & \multirow{5}{*}{$\begin{array}{l}64 \\
\%\end{array}$} & \multirow[t]{3}{*}{ Practicing } & \multirow{3}{*}{$\begin{array}{l}8 / 12 \\
(66 \\
\%)\end{array}$} & \multirow{3}{*}{$\begin{array}{l}8 / 12 \\
(66 \\
\%)\end{array}$} & $\begin{array}{l}\text { Repeating and } \\
\text { imitating }\end{array}$ & 4 & 3 \\
\hline & & & & & & $\begin{array}{l}\text { Formally practicing } \\
\text { with sounds and } \\
\text { writing systems }\end{array}$ & 1 & 2 \\
\hline & & & & & & $\begin{array}{l}\text { Practicing } \\
\text { naturalistically }\end{array}$ & 3 & 3 \\
\hline & & & \multirow{2}{*}{$\begin{array}{l}\text { Receiving } \\
\text { and sending } \\
\text { messages }\end{array}$} & \multirow{2}{*}{$\begin{array}{l}4 / 7 \\
(57 \\
\%)\end{array}$} & \multirow{2}{*}{$\begin{array}{l}6 / 7 \\
(86 \\
\%)\end{array}$} & $\begin{array}{l}\text { Getting the idea } \\
\text { quickly }\end{array}$ & 2 & 4 \\
\hline & & & & & & $\begin{array}{l}\text { Using resources for } \\
\text { receiving and } \\
\text { sending messages }\end{array}$ & 2 & 2 \\
\hline & & & $\begin{array}{l}\text { Analysing } \\
\text { and } \\
\text { reasoning }\end{array}$ & $\begin{array}{l}3 / 4 \\
(75 \\
\%) \\
\end{array}$ & $\begin{array}{l}3 / 4 \\
(75 \\
\%)\end{array}$ & Translating & 3 & 3 \\
\hline & & & $\begin{array}{l}\text { Creating } \\
\text { structure for }\end{array}$ & $\begin{array}{l}1 / 5 \\
(20\end{array}$ & $\begin{array}{l}1 / 5 \\
(20\end{array}$ & Taking notes & - & - \\
\hline & & & input and & $\%)$ & $\%)$ & Summarizing & 1 & 1 \\
\hline & & & output & & & Highlighting & - & - \\
\hline \multirow{6}{*}{$\begin{array}{l}\text { Comp } \\
\text { ensatio } \\
\text { n } \\
\text { strateg } \\
\text { ies }\end{array}$} & \multirow{6}{*}{$\begin{array}{l}50 \\
\%\end{array}$} & \multirow{6}{*}{$\begin{array}{l}81 \\
\%\end{array}$} & $\begin{array}{l}\text { Guessing } \\
\text { intelligently }\end{array}$ & $\begin{array}{l}2 / 4 \\
(50 \\
\%) \\
\end{array}$ & $\begin{array}{l}4 / 4 \\
(100 \\
\%) \\
\end{array}$ & $\begin{array}{l}\text { Using non-linguistic } \\
\text { clues }\end{array}$ & 2 & 4 \\
\hline & & & \multirow{5}{*}{$\begin{array}{l}\text { Overcoming } \\
\text { limitations }\end{array}$} & \multirow{5}{*}{$\begin{array}{l}6 / 12 \\
(50 \\
\%)\end{array}$} & \multirow{5}{*}{$\begin{array}{l}9 / 12 \\
(75 \\
\%)\end{array}$} & $\begin{array}{l}\text { Switching to the } \\
\text { mother tongue }\end{array}$ & - & - \\
\hline & & & & & & Getting help & 5 & 6 \\
\hline & & & & & & $\begin{array}{lll}\begin{array}{l}\text { Using } \\
\text { gesture }\end{array} & \text { mime } & \text { or } \\
\end{array}$ & - & 1 \\
\hline & & & & & & Selecting the topic & - & - \\
\hline & & & & & & $\begin{array}{l}\text { Using } \\
\text { circumlocution or } \\
\text { synonym }\end{array}$ & 1 & 2 \\
\hline \multirow{4}{*}{$\begin{array}{l}\text { Metac } \\
\text { ognitiv } \\
\text { e } \\
\text { strateg } \\
\text { ies }\end{array}$} & 77 & 61 & $\begin{array}{l}\text { Centring } \\
\text { your } \\
\text { learning }\end{array}$ & $\begin{array}{l}4 / 5 \\
(80 \\
\%)\end{array}$ & $\begin{array}{l}2 / 5 \\
(40 \\
\%)\end{array}$ & Paying attention & 4 & 2 \\
\hline & $\%$ & $\%$ & $\begin{array}{l}\text { Arranging } \\
\text { and }\end{array}$ & $\begin{array}{l}5 / 6 \\
(83\end{array}$ & $\begin{array}{l}4 / 6 \\
(66\end{array}$ & $\begin{array}{l}\text { Planning for } a \\
\text { language task }\end{array}$ & 3 & 3 \\
\hline & & & $\begin{array}{l}\text { planning } \\
\text { your } \\
\text { learning }\end{array}$ & $\%)$ & $\%)$ & $\begin{array}{l}\text { Seeking practice } \\
\text { opportunities }\end{array}$ & 2 & 1 \\
\hline & & & $\begin{array}{l}\text { Evaluating } \\
\text { your }\end{array}$ & $\begin{array}{l}1 / 2 \\
(50\end{array}$ & $\begin{array}{l}2 / 2 \\
(100\end{array}$ & Self-monitoring & 1 & 2 \\
\hline
\end{tabular}




\begin{tabular}{|l|l|l|l|l|l|l|l|l|}
\hline & & & learning & $\%)$ & $\%)$ & & & \\
\hline Total & & & & $37 / 6$ & $43 / 6$ & & $37 /$ & $42 /$ \\
& & & & 5 & 5 & & 65 & 65 \\
\hline
\end{tabular}

Based on the results the gifted learners (G) use actively 37 out of 64 learning strategies $\mathbf{( 5 8 \% )}$ ) itemised in the inventory. Broken down into subsections, the learners make use of $\mathbf{3 7 \%}$ of the memory strategies, $\mathbf{5 7 \%}$ of the cognitive strategies, $\mathbf{5 0 \%}$ of the compensation strategies and $\mathbf{7 7 \%}$ of the metacognitive strategies.

The learners in traditional classes (T) apply actively 43 out of 65 learning strategies $(66 \%)$ specified in the inventory. They use $37 \%$ of the memory strategies, $\mathbf{6 8 \%}$ of the cognitive strategies, $\mathbf{8 1 \%}$ of the compensation strategies and $\mathbf{6 1 \%}$ of the metacognitive strategies.

To sum up, both the gifted and learners in traditional class use the same amount of memory strategies. The learners in the traditional class use more cognitive and compensation strategies whereas the gifted learners apply more metacognitive strategies.

In the subsequent tables the four basic strategy groups are subdivided into strategy sets and distinct strategies. To gain a deeper insight into the learners`strategy use, a more profound analysis of individual strategies and their examples is provided.

Table 3 Memory strategies

\begin{tabular}{|c|c|c|c|}
\hline $\begin{array}{l}\text { Strategy set } \\
\text { Strategy }\end{array}$ & & Gifted & $\begin{array}{c}\text { Traditi } \\
\text { onal }\end{array}$ \\
\hline $\begin{array}{l}\text { Creating mental linkages } \\
\text { Associating, elaborating }\end{array}$ & $\begin{array}{l}\text { 16. I match the sound of the new } \\
\text { word with the sound of a word I } \\
\text { know. }\end{array}$ & $92 \%$ & $67 \%$ \\
\hline $\begin{array}{l}\text { Applying images and } \\
\text { sounds } \\
\text { Using imagery }\end{array}$ & $\begin{array}{l}\text { 18. I make a picture of new words } \\
\text { in my mind. }\end{array}$ & $69 \%$ & $100 \%$ \\
\hline $\begin{array}{l}\text { Reviewing well } \\
\text { Structured reviewing }\end{array}$ & $\begin{array}{l}\text { 22. Later I go to remind myself } \\
\text { about words I learned earlier. }\end{array}$ & $77 \%$ & $67 \%$ \\
\hline
\end{tabular}

According to Oxford (1990) memory strategies help learners store and retrieve new information when needed for communication. They reflect simple principles which all involve meaning.

Associating and elaborating means relating new language information to concepts already in memory, or relating one piece of information to another, to create associations in memory. Gifted learners clearly tend to apply this strategy more frequently than the learners in traditional classes; the difference makes $25 \%$.

Using imagery means relating new language information to concepts in memory by means of meaningful visual imagery, either in the mind or in the actual drawing. This strategy is obviously more preferred by the learners in traditional classes; the difference makes $31 \%$. 
Structured reviewing reflects the idea that looking at new language information is not enough; it must be reviewed in order to be remembered. The goal is being so familiar with the information that it becomes automatic. This strategy finds more application by gifted learners; the difference makes $10 \%$.

Table 4 Cognitive strategies

\begin{tabular}{|c|c|c|c|}
\hline $\begin{array}{l}\text { Strategy set } \\
\text { Strategy }\end{array}$ & & Gifted & $\begin{array}{c}\text { Traditio } \\
\text { nal }\end{array}$ \\
\hline $\begin{array}{l}\text { Practicing } \\
\text { Practicing naturalistically }\end{array}$ & $\begin{array}{l}\text { 1. I listen to the radio or songs in the } \\
\text { language. }\end{array}$ & $85 \%$ & $100 \%$ \\
\hline $\begin{array}{l}\text { Practicing } \\
\text { Practicing naturalistically }\end{array}$ & $\begin{array}{l}\text { 2. I watch TV shows or videos in the } \\
\text { language. }\end{array}$ & $61.5 \%$ & $67 \%$ \\
\hline $\begin{array}{l}\text { Practicing } \\
\text { Practicing naturalistically }\end{array}$ & 34. I read for fun in the language. & $85 \%$ & $67 \%$ \\
\hline $\begin{array}{l}\text { Practicing } \\
\text { Repeating and imitating }\end{array}$ & $\begin{array}{l}\text { 21. I go over new words several } \\
\text { times at first. }\end{array}$ & $92 \%$ & $100 \%$ \\
\hline $\begin{array}{l}\text { Practicing } \\
\text { Repeating and imitating }\end{array}$ & $\begin{array}{l}\text { 23. I make the sounds of the } \\
\text { language until I can say them well. }\end{array}$ & $69 \%$ & $67 \%$ \\
\hline $\begin{array}{l}\text { Practicing } \\
\text { Repeating and imitating }\end{array}$ & $\begin{array}{l}\text { 24. I imitate the way native speakers } \\
\text { talk. }\end{array}$ & $77 \%$ & - \\
\hline $\begin{array}{l}\text { Practicing } \\
\text { Repeating and imitating }\end{array}$ & 39. I read things more than once. & - & $89 \%$ \\
\hline $\begin{array}{l}\text { Practicing } \\
\text { Repeating and imitating }\end{array}$ & $\begin{array}{l}57 \text {. I rewrite what I wrote to make it } \\
\text { better. }\end{array}$ & $61 \%$ & $87.5 \%$ \\
\hline $\begin{array}{l}\text { Practicing } \\
\text { Formally practicing with } \\
\text { sounds and writing systems }\end{array}$ & $\begin{array}{l}\text { 25. I say new expressions over to } \\
\text { myself. }\end{array}$ & $61 \%$ & $67 \%$ \\
\hline $\begin{array}{l}\text { Practicing } \\
\text { Formally practicing with } \\
\text { sounds and writing systems }\end{array}$ & $\begin{array}{l}\text { 49. If the alphabet is different, I } \\
\text { practice writing it. }\end{array}$ & - & $87.5 \%$ \\
\hline $\begin{array}{l}\text { Receiving and sending } \\
\text { messages } \\
\text { Getting the idea quickly }\end{array}$ & $\begin{array}{l}\text { 37. I skim over a reading to get the } \\
\text { main idea. }\end{array}$ & - & $78 \%$ \\
\hline $\begin{array}{l}\text { Receiving and sending } \\
\text { messages } \\
\text { Getting the idea quickly }\end{array}$ & 38. I look for important facts. & $85 \%$ & $89 \%$ \\
\hline $\begin{array}{l}\text { Receiving and sending } \\
\text { messages } \\
\text { Getting the idea quickly }\end{array}$ & $\begin{array}{l}\text { 40. I look at the pictures and what is } \\
\text { under the pictures. }\end{array}$ & $92 \%$ & $78 \%$ \\
\hline $\begin{array}{l}\text { Receiving and sending } \\
\text { messages } \\
\text { Getting the idea quickly }\end{array}$ & 41. I look at the headings. & - & $100 \%$ \\
\hline $\begin{array}{l}\text { Receiving and sending } \\
\text { messages } \\
\text { Using resources for } \\
\text { receiving and sending } \\
\text { messages }\end{array}$ & $\begin{array}{l}\text { 48. I use a dictionary to find the } \\
\text { meaning. }\end{array}$ & $92 \%$ & $75 \%$ \\
\hline $\begin{array}{l}\text { Receiving and sending } \\
\text { messages } \\
\text { Using resources for } \\
\text { receiving and sending }\end{array}$ & 54. I use a dictionary or glossary. & $92 \%$ & $87.5 \%$ \\
\hline
\end{tabular}




\begin{tabular}{|c|c|c|c|}
\hline messages & & & \\
\hline $\begin{array}{l}\text { Analysing and reasoning } \\
\text { Translating }\end{array}$ & $\begin{array}{l}\text { 62. I translate when reading to make } \\
\text { sure I understand it. }\end{array}$ & $77 \%$ & $87.5 \%$ \\
\hline $\begin{array}{l}\text { Analysing and reasoning } \\
\text { Translating }\end{array}$ & $\begin{array}{l}\text { 63. While I am listening to someone, } \\
\text { I translate parts of what they say into } \\
\text { my own language to help remember } \\
\text { it. }\end{array}$ & - & $62.5 \%$ \\
\hline $\begin{array}{l}\text { Analysing and reasoning } \\
\text { Translating }\end{array}$ & $\begin{array}{l}\text { 64. I try to understand without } \\
\text { translating. }\end{array}$ & $77 \%$ & $75 \%$ \\
\hline $\begin{array}{l}\text { Creating structure for input } \\
\text { and output } \\
\text { Summarizing }\end{array}$ & $\begin{array}{l}\text { 43. I stop to think about what I just } \\
\text { read. }\end{array}$ & $61 \%$ & $78 \%$ \\
\hline
\end{tabular}

According to Oxford (1990) cognitive strategies enable learners to understand and produce new language. They are essential in learning new language and are unified by a common function: manipulation or transformation of the target language by the learner. The high number of the listed strategies suggests that this strategy group is very broad.

The strategy sets that are according to the learners reports used in a relevant amount are: Practicing (practicing naturalistically, repeating and imitating, formally practicing with sounds and writing systems), Receiving and sending messages (getting the idea quickly, using resources for receiving

414 and sending messages), Analysing and reasoning (translating) and Creating structure for input and output (summarizing). Examining each strategy group in more detail, the following outcomes can be observed.

Practicing naturalistically (ibid.) is practicing the new language in realistic settings, e.g. participating in a conversation, reading a book or article, listening to a lecture, or writing a letter in the new language. Compared to the learners in traditional classes the gifted learners prefer the strategy "reading for fun in the language", whereas the learners in traditional classes favour the strategies "listening to the radio or songs in the language" and "watching TV shows or videos in the language".

Repeating and imitating means saying or doing something over and over e.g. listening to something several times, rehearsing, imitating a native speaker. Formally practicing with sounds and writing systems is practicing in a variety of ways. The common feature of these two strategy sets is the non-naturalistic communicative practice. In the most cases it seems to be favoured by the learners in traditional classes with one exception - they do not imitate the way native speakers talk. On the other hand, gifted learners do not read things more than once and do not practice writing different alphabet.

Getting the idea quickly (ibid.) means using skimming to determine the main idea or scanning to find specific details. This strategy helps learners understand rapidly what they hear or read in the new language. Interestingly, strategies in this strategy set seem to be applied more frequently by the learners in traditional classes than by the gifted learners

Slavonic Pedagogical Studies Journal, ISSN 1339-866o, Volume 5 Issue 2, September 2016 
with one exception. They use less frequent the strategy "looking at the pictures and what is under the pictures".

Using resources for receiving and sending messages means using print or non-print resources to understand incoming messages or produce outgoing messages and according to the research outcomes this strategy set is used more frequently by the gifted pupils.

Translating (ibid.) means using one language as the basis for understanding or producing another such as converting either target language expressions into the native language or vice versa at various levels from words and phrases up to whole texts. Generally, these strategies are not very desirable in foreign language learning and use. We would like to point out that gifted learners show lower tendency towards using these strategies.

Summarizing is a strategy for making a summary of a longer written or spoken passage. This strategy is applied more frequently by the learners in traditional classes.

Table 5 Compensation strategies

\begin{tabular}{|c|c|c|c|}
\hline $\begin{array}{l}\text { Strategy set } \\
\text { Strategy }\end{array}$ & & $\begin{array}{c}\text { Gifte } \\
\text { d }\end{array}$ & $\begin{array}{c}\text { Traditi } \\
\text { onal }\end{array}$ \\
\hline $\begin{array}{l}\text { Overcoming limitations } \\
\text { Getting help }\end{array}$ & 9. I ask the person to repeat. & $92 \%$ & $78 \%$ \\
\hline $\begin{array}{l}\text { Overcoming limitations } \\
\text { Getting help }\end{array}$ & 11. I ask a question. & $77 \%$ & $78 \%$ \\
\hline $\begin{array}{l}\text { Overcoming limitations } \\
\text { Getting help }\end{array}$ & $\begin{array}{l}\text { 29. I ask the other person to correct } \\
\text { me when I talk. }\end{array}$ & - & $67 \%$ \\
\hline $\begin{array}{l}\text { Overcoming limitations } \\
\text { Getting help }\end{array}$ & 30. I ask the person to help me. & $100 \%$ & $89 \%$ \\
\hline $\begin{array}{l}\text { Overcoming limitations } \\
\text { Getting help }\end{array}$ & $\begin{array}{l}56 . \text { I ask someone to correct my } \\
\text { writing. }\end{array}$ & $100 \%$ & $75 \%$ \\
\hline $\begin{array}{l}\text { Overcoming limitations } \\
\text { Getting help }\end{array}$ & $\begin{array}{l}\text { 59. I ask someone for the word or } \\
\text { phrase I need. }\end{array}$ & $100 \%$ & $87.5 \%$ \\
\hline $\begin{array}{l}\text { Overcoming limitations } \\
\text { Using circumlocution } \\
\text { or synonym }\end{array}$ & 31. I try to say it a different way. & $61 \%$ & $67 \%$ \\
\hline $\begin{array}{l}\text { Overcoming limitations } \\
\text { Using circumlocution } \\
\text { or synonym }\end{array}$ & 60. I try to write it a different way. & - & $75 \%$ \\
\hline $\begin{array}{l}\text { Overcoming limitations } \\
\text { Using mime or gesture }\end{array}$ & 33. I use body language. & - & $89 \%$ \\
\hline $\begin{array}{l}\text { Guessing intelligently } \\
\text { Using non-linguistic } \\
\text { clues }\end{array}$ & $\begin{array}{l}\text { 12. I guess the meaning from the } \\
\text { person's tone (such as angry or } \\
\text { happy). }\end{array}$ & - & $89 \%$ \\
\hline $\begin{array}{l}\text { Guessing intelligently } \\
\text { Using non-linguistic } \\
\text { clues }\end{array}$ & $\begin{array}{l}\text { 13. I guess the meaning from how } \\
\text { the person moves or stands. }\end{array}$ & - & $78 \%$ \\
\hline $\begin{array}{l}\text { Guessing intelligently } \\
\text { Using non-linguistic }\end{array}$ & $\begin{array}{l}\text { 14. I guess the meaning from what } \\
\text { I heard before. }\end{array}$ & $92 \%$ & $78 \%$ \\
\hline
\end{tabular}




\begin{tabular}{|l|l|l|l|}
\hline clues & & & \\
\hline $\begin{array}{l}\text { Guessing intelligently } \\
\begin{array}{l}\text { Using non-linguistic } \\
\text { clues }\end{array}\end{array}$ & $\begin{array}{l}\text { 47. I guess the meaning by using } \\
\text { clues from other parts of the } \\
\text { passage. }\end{array}$ & $\mathbf{8 5 \%}$ & $\mathbf{1 0 0 \%}$ \\
\hline
\end{tabular}

According to Oxford (1990) compensation strategies allow learners to use the new language for either comprehension or production despite gaps in knowledge. The strategy sets that are according to the learners reports used in a relevant amount are: Overcoming limitations (getting help, using circumlocution or synonym, using mime or gesture) and Guessing intelligently (using non-linguistic clues).

The strategy Getting help is used by both groups of learners. However, the gifted learners apply it more frequently.

Using circumlocution or synonym (ibid.) means getting the meaning across by describing the concept or using a word that means the same thing and is, interestingly, favoured more by the learners in traditional classes.

The same can be observed with the strategy Using mime or gesture which means using physical motion in a place of an expression to indicate the meaning.

Using non-linguistic clues (ibid.) is using not language-based clues in order to guess the meaning of what is heard or read in the target language. Nonlanguage clues may be represented by: knowledge of context, situation, text structure, personal relationships, topic or general world knowledge. These strategies are used predominantly by the learners in traditional classes with the exception of the strategy "guessing the meaning from what I heard before", which is applied mainly by the gifted learners.

Table 6 Metacognitive strategies

\begin{tabular}{|l|l|l|l|}
\hline $\begin{array}{l}\text { Strategy set } \\
\text { Strategy }\end{array}$ & \multicolumn{1}{|c|}{$\begin{array}{c}\text { Gifte } \\
\text { d }\end{array}$} & $\begin{array}{c}\text { Traditi } \\
\text { onal }\end{array}$ \\
\hline $\begin{array}{l}\text { Centering your learning } \\
\text { Paying attention } \\
\text { guided and selective } \\
\text { attention) }\end{array}$ & $\begin{array}{l}\text { 3. If I hear people speaking the } \\
\text { language, I listen. }\end{array}$ & $\mathbf{6 9 \%}$ & - \\
\hline $\begin{array}{l}\text { Centering your learning } \\
\text { Paying attention } \\
\text { (guided and selective } \\
\text { attention) }\end{array}$ & $\begin{array}{l}\text { 5. I try to remember unfamiliar } \\
\text { sounds I hear. }\end{array}$ & $\mathbf{8 5 \%}$ & $\mathbf{1 0 0 \%}$ \\
\hline $\begin{array}{l}\text { Centering your learning } \\
\text { Paying attention } \\
\text { guided and selective } \\
\text { attention) }\end{array}$ & 6. I listen for the important words. & $\mathbf{8 5 \%}$ & $\mathbf{1 0 0 \%}$ \\
\hline $\begin{array}{l}\text { Centering your learning } \\
\text { Paying attention } \\
\text { (guided and selective } \\
\text { attention) }\end{array}$ & $\begin{array}{l}\text { 8. I listen for words that are } \\
\text { repeated. }\end{array}$ & $\mathbf{7 7 \%}$ & - \\
\hline
\end{tabular}

Slavonic Pedagogical Studies Journal, ISSN 1339-866o, Volume 5 Issue 2, September 2016 


\begin{tabular}{|c|c|c|c|}
\hline $\begin{array}{l}\text { Arranging and planning } \\
\text { your learning } \\
\text { Seeking practice } \\
\text { opportunities }\end{array}$ & $\begin{array}{l}\text { 35. I find things to read that } \\
\text { interest me. }\end{array}$ & $69 \%$ & - \\
\hline $\begin{array}{l}\text { Arranging and planning } \\
\text { your learning } \\
\text { Seeking practice } \\
\text { opportunities }\end{array}$ & $\begin{array}{l}\text { 36. I look for things to read that } \\
\text { are not too hard. }\end{array}$ & $61 \%$ & $89 \%$ \\
\hline $\begin{array}{l}\text { Arranging and planning } \\
\text { your learning } \\
\text { Planning for a } \\
\text { language tasks }\end{array}$ & 28. I plan what I am going to say. & $69 \%$ & $67 \%$ \\
\hline $\begin{array}{l}\text { Arranging and planning } \\
\text { your learning } \\
\text { Planning for a } \\
\text { language tasks }\end{array}$ & $\begin{array}{l}\text { 42. I think about what will come } \\
\text { next in the reading. }\end{array}$ & $61 \%$ & $78 \%$ \\
\hline $\begin{array}{l}\text { Arranging and planning } \\
\text { your learning } \\
\text { Planning for a } \\
\text { language tasks }\end{array}$ & $\begin{array}{l}\text { 53. I plan what I am going to } \\
\text { write. }\end{array}$ & - & $75 \%$ \\
\hline $\begin{array}{l}\text { Arranging and planning } \\
\text { your learning } \\
\text { Planning for a } \\
\text { language tasks }\end{array}$ & $\begin{array}{l}\text { 61. I plan what I want to say or } \\
\text { write in my language and then } \\
\text { translate it into the new language. }\end{array}$ & $85 \%$ & - \\
\hline $\begin{array}{l}\text { Evaluating your } \\
\text { learning } \\
\text { Self-monitoring }\end{array}$ & $\begin{array}{l}\text { 46. I check to see how much I } \\
\text { understood }\end{array}$ & - & $87.5 \%$ \\
\hline $\begin{array}{l}\text { Evaluating your } \\
\text { learning } \\
\text { Self-monitoring }\end{array}$ & $\begin{array}{l}55 . \text { I read what I wrote to see if it } \\
\text { is good. }\end{array}$ & $92 \%$ & $100 \%$ \\
\hline
\end{tabular}

According to Oxford (1990) metacognitive strategies allow learners to control their own cognition - to coordinate the learning process by using functions such as centering, arranging, planning and evaluating. Metacognitive means beyond or beside cognitive. The strategy sets that are according to the learners reports used in a relevant amount are: Centering one's learning (paying guided and selective attention) and Arranging and planning one's learning (seeking practice opportunities, planning for a language tasks, self-monitoring).

Paying attention means making a decision to pay attention in general to a language task. The gifted learners use more strategies for paying attention than the learners in traditional classes who do not apply the strategies "listening to people speaking the language" and "listening for words that are repeated".

Seeking practice opportunities (ibid.) represents a strategy for consciously thinking in the new language which also provides practice opportunities. Both strategies in this set ("I find things to read that interest me" and I look for things to read that are not too hard) are used by the gifted learners, whereas the learners in traditional classes apply only the second strategy. 
Planning for a language tasks means planning for the language elements and functions necessary for an anticipated language task or situation. The use of strategies within this strategy set is well balanced. Each group of learners uses three strategies from the set. The difference in the application is observable in two cases. Gifted learners do not utilize the strategy "I plan what I am going to write" in relevant amount, whereas the learners in traditional classes do not apply the strategy "I plan what I want to say or write in my language and then translate it into the new language" sufficiently.

Self-monitoring (ibid.) means identifying errors in understanding or producing the new language, determining which ones are important, tracking the source of important errors, and trying to eliminate such errors. Both strategies from this set are used by the learners in the traditional classes very frequently, whereas the gifted learners apply only the strategy "reading what I wrote to see if it is good".

\section{Interpretations of the Results}

It is obvious from the results in the Tables 1 and 2 that metacognitive strategies present the group which is used most by the gifted learners. According to Oxford $(1900$, p. 136) they are "actions which go beyond purely cognitive devices and which provide a way for learners to coordinate their own learning processes". The learners favour mainly the strategy for paying attention - it means they decide in advance to pay attention in general to a language task and to ignore distractors or to pay attention to the specifics of the language. Arranging and planning the learning is another strategy which plays an important role for the learners. It is connected with planning what the learners want to say or write and with thinking about what will come next in the reading or listening text. The strategy for seeking practice opportunities, which means practicing the new language in naturalistic situations (authentic reading or listening) takes also significant part of their learning process. Evaluating one's own learning is the metacognitive strategy which is employed less often - this outcome corresponds with the findings of other researchers according to which strategies for evaluating one's own learning do not find sufficient application in the learning process.

The second position is occupied by the cognitive strategies where analysing and reasoning represented by the strategy translation is the most common one. Transforming the target language predominantly by repeating, imitating and practicing naturalistically is also important. Repeating which means saying or doing something over and over, such as going over new vocabulary, rehearsing or imitating native speakers. Practicing the new language in realistic settings is done mostly by practicing the receptive skills listening and reading such as listening to radio, songs or watching films and TV shows. Over a half of the strategies for receiving and sending messages, which means extracting ideas by skimming or scanning to find specific details of interest and using print or non-print resources to understand incoming messages or produce outgoing messages, is used by

Slavonic Pedagogical Studies Journal, ISSN 1339-8660, Volume 5 Issue 2, September 2016 
the gifted learners. However, the cognitive strategies for creating structure for input and output such as taking notes, summarizing and highlighting are applied fairly seldom. They involve writing down the main idea or specific points, making summaries of a longer passage and using a variety of emphasis techniques to focus on important information in a passage. The gifted learners seemingly do not need to structure the new input into manageable chunks.

Compensation strategies take the third place in the hierarchy of the strategy use. Guessing strategies also called inferencing involve clues to guess the meaning when the learner does not know all the words. Good language learners, when confronted with unknown expressions, make educated guesses - a way of interpreting the data by using the immediate context, situation, text structure, personal relationships, general world knowledge or one's own experience. The strategy group overcoming limitations is represented mainly by the strategy asking for help by hesitating or explicitly asking the person to provide the missing expression in the target language. Gifted learners seem to prefer strategies involving learners' choices to interact with other learners and native speakers, such as asking questions to clarify social roles and relationships, asking for an explanation or verification, and cooperating with others in order to complete tasks. They apply these strategies to higher extent than learners in traditional classes. Oxford (1990) suggests that strategies like getting help may lead learners to gain new information about what is suitable or acceptable in the target language. According to her learners skilled in such strategies sometimes communicate better than leaners who know more target language words and structures. The only exception is represented by the strategy "asking the other person to correct one when s/he talks" which is not used by the gifted learners in a relevant amount.

Considering the memory strategies approximately one third of strategies involved in this strategy group are used. The most prevalent is the strategy structured reviewing. Its purpose is being so familiar with the information that it becomes natural and automatic. Using imagery, a strategy belonging to the set applying images and sounds, is used to remember abstract words by associating them with a picture or a concrete object. Least common is the strategy group creating mental linkages which is represented by the strategy associating and elaborating. Its purpose is to relate language information to another to concepts already in memory.

As for the learners in the traditional classes, the following order of importance in using the learning strategies can be observed. They show inclination towards using preferably compensation strategies. Within this strategy group, the strategy guessing intelligently by using not languagebased clues in order to guess the meaning of what is heard or read in the target language is used to $100 \%$. This strategy group represents special way learners process new information. They interpret the data by using the immediate context and their own life experience. The strategy set overcoming limitations is applied to $75 \%$.

The second most frequently used strategy group are the cognitive strategies, same as with gifted learners. The only difference can be seen in the use of 
the strategy set receiving and sending messages which seems to be applied by learners in the traditional classes more often (86\%), especially extracting ideas by skimming or scanning to find specific details of interest.

Metacognitive strategies take the third place in the hierarchy of the strategy use of the surveyed learners in traditional classes. Interestingly, the strategy set evaluating one's learning by self-monitoring shows more frequent use $(100 \%)$ than with the gifted learners $(50 \%)$. This finding is in contradiction with the research outcomes of other scholars. In comparison, gifted learners favour using metacognitive strategies for centring and planning one's learning by paying attention, planning for a language task and seeking practice opportunities.

The last position is occupied by the memory strategies. The results in all memory strategy groups and strategy sets overlap completely with the data obtained from the gifted learners - approximately one third of strategies involved in this strategy group are used by the learners in the traditional classes.

\section{Conclusion}

Some researchers state that language learners rarely report using memory strategies. This statement can be confirmed also by our findings both in the case of the gifted pupils as well as the learners in traditional classes. Oxford (1990) offers two possible explanations: they either do not use memory strategies beyond elementary levels of language learning or they are unaware of employing them. Our survey outcomes support the findings mentioned above as both learner groups reported rather sporadic use of the memory strategies in all categories (37\% each).

According to Oxford (1990) the cognitive strategies are found to be the most popular with the language learners. We can confirm this statement. Based on our findings $57 \%$ of the cognitive strategies are used by gifted pupils and even $64 \%$ by the learners in traditional classes.

Interestingly, according to our research the cognitive strategies are not used to such an extent as the metacognitive strategies by the gifted learners and compensation strategies by the learners in traditional classes. In the use of these two strategy groups the most obvious differences were found out.

According to Oxford (1990) metacognitive strategies are extremely important, however, the research shows the learners use these strategies sporadically and without much sense of their importance. As opposed to several studies of foreign and second language learning which state that learners use metacognitive strategies less often than cognitive strategies (Oxford, 1990) our findings in the group of gifted learners demonstrate an opposite situation.

Compensation strategies allow learners to use the new language for either comprehension or production despite gaps in knowledge or inadequate repertoire of grammar and vocabulary. The learners in traditional classes reported very high use of this strategy group. The possible explanation could be that less proficient learners need these strategies more, because they come across knowledge obstructions more often than skilled ones. 
The results obtained within this small-scale pilot research cannot be generalized and need to be supplied by further research with more research subjects. We would also recommend a combination of the quantitative data collection with qualitative methodology (such as in-depth interviews, thinkaloud protocol, or designing tasks that are aimed at measuring the use of various strategies). Finally, the small-scale character of the research suggests the application of a case study approach in which individual foreign language learning strategies of single learners would be examined.

\section{Bibliographic references}

ABRAHAM, R. G. - VANN, R. J. 1987. Strategies of two language learners: A case study. In Wenden and Rubin (Eds.), Learner strategies in language learning. Englewood Cliffs, NJ: Prentice-Hall.

BIALYSTOK, E. 1979. The role of conscious strategies in second language proficiency. Modern Language Journal, vol. 65, pp. 24-35.

BIROVA, J. 2013. About theoretical definitions of pluralistic and Pluricultural approaches. XLinguae. vol. 6, n. 2, pp. 91-103. ISSN 13378384.

Council of Europe 2011. Common European Framework of Reference for Languages: Learning, Teaching, Assessment (CEFR) Available online: http://www.coe.int/t/dg4/linguistic/Source/Framework_EN.pdf.

COHEN, A. D. - WEAVER, S. J. 2005. Styles and Strategies-Based Instruction: A Teachers' Guide. CARLA Working Paper Series Center for Advanced Research on Language Acquisition.

CHAMOT, A. U. 1987. The learning strategies of ESL students. In A. Wenden \& J. Rubin (Eds.) Learner strategies in language learning (pp. 7183). Englewood Cliffs, NJ: Prentice/Hall International.

CHAMOT, A. U. - KUPPER, L. 1989. Learning strategies in foreign language instruction. Foreign Language Annual, vol. 22, pp. 13-24.

DOCKAL, V. 2005. Zaměrěno na talenty, aneb, Nadání má každý. Praha: Nakladatelství Lidové noviny. ISBN 8071068403.

DUCHOVICOVÁ, J. 2007. Aspekty diferenciácie v edukácií nadaných žiakov. Nitra: UKF. ISBN 9788080940997.

DUCHOVIČOVÁ, J. 2009. Jazykové nadanie a jeho pedagogicko-psychosociálny aspect. In: Pokrivčáková, S.: Cudzie jazyky a kultúry v modernej škole. Brno: PF MU. pp. 43-71. ISBN 9788021049741.

DUCHOVIČOVÁ, J. - BABULICOVÁ, Z. 2010. Podpora nadania diet’ata v predškolskom veku. In: Šimoník, O.: Vzdelávání nadaných žáků. Brno: PF MU. pp. 155-173. ISBN 9788021053496.

EHRMAN, M. - OXFORD, R. 1995. Cognitive plus: correlations of language learning success. Modern Language Journal, vol. 79, pp. 67-89. Online ISSN 1540-4781.

FISHER, R. 2004. Učíme deti myslet a učit se. Praktický průvodce stratégiemi vyučování. Praha: Portal. ISBN 8071789666.

GAGNÉ, F. 1985. Giftedness and talent: Reexamining a reexamination of the definitions. Gifted Child Quarterly. vol. 29, p. 103-112. Online ISSN: 1934-9041 
GOTTFREDSON, L. S. 2011. Intelligence and social inequality: Why the biological link? In: Chamorro-Premuzic, T.; Furhnam, A. \& S. von Stumm (Eds.), Handbook of Individual Differences. (p. 538-575). Wiley-Blackwell. HASSELHORN, M. - LABUHN, A. S. 2010. Lernstrategien. In Hascher T. \& Schmitz, B. (Hrsg.), Pädagogische Interventionsforschung. Weinheim/München: Juventa Verlag.

HORVÁTHOVÁ, B. 2013a. Methods in Researching and Teaching Language Learning Strategies. Nitra : ASPA, 2013. ISBN 978-80-89477$11-1$.

HORVÁTHOVÁ, B. 2013b. Language Learning Strategies in Listening Comprehension. Nitra : ASPA, 2013. ISBN 978-80-89477-13-5.

HORVÁTHOVÁVÁ, B. \& REID, E. 2013. Parents' reflections on the education of gifted children in Slovakia, 2013. XLinguae, vol. 6, no. 1, pp. 30-49. ISSN 1337-8384.

JOHNSEN, S, K. 2011. Identifying Gifted Students: A Practical Guide. Prufrock Press. ISBN 9781593637019.

KLÍMOVÁ, B. 2015. Assessment in smart learning environment - a case study approach. Smart Innovation, Systems and Technologies. vol. 41. Springer. ISSN 21903018.

KOVÁČIKOVÁ. E. 2015. Teaching English to Learners with Specific Learnging Needs. In: Pokrivčáková. S. Teaching foreign languages to learners with special educational needs in Slovakia. p. 29-38. ISBN 9788097158071.

422 LAZNIBATOVÁ, J. 1996. Problémy výchovy a vzdelávania nadaných detí. (Projekt starostlivosti o nadané deti v podmienkach základných škôl). In: Pedagogická revue. vol. 1, n. 1-2, pp. 79-84. ISSN 13351982.

LAZNIBATOVÁ, J. 1998. Sociálne vztahy a atmosféra výchovnovzdelávacieho procesu v triedach pre nadané deti. In: Zborník prríspěvkủ, č. 3. Šlapanice u Brna, 5. zjazd Asociácie školskej psychológie SR a ČR.

LAZNIBATOVÁ, J. 2001. Nadané diet’a: jeho vývin, vzdelávanie a podporovanie. Bratislava: Iris. ISNB 8088778238.

LAZNIBATOVÁ, J. 2007. Nadané diet'a. Jeho vývin, vzdelávanie a podporovanie. Bratislava: Iris. ISBN 9788089256990.

LAZNIBATOVÁ, J. 2008. Od rozvíjania nadania k rozvíjaniu osobitosti nadaných. Zborník prác z 5. Medzinárodnej konferencie. Bratislava. Iris. LAZNIBATOVÁ, J. 2012. Nadaný žiak. Na základnej, strednej a vysokej škole. Bratislava: Iris. ISBN 9788089256877.

O'MALLEY, J. M. \& CHAMOT, A. U. 1990. Learning strategies in second language acquisition. New York: Cambridge University Press. Online ISBN 9781139524490.

OXFORD, R. \& NYIKOS, M. 1989. Variables affecting choices of language learning strategies by university students. Modern Language Journal, vol. 73, pp. 291-300. Online ISSN: 1540-4781.

OXFORD, R. 1989. Use of language learning strategies: A synthesis of studies with implications for strategy training. System, vol. 17, n. 2, pp. 235-247. ISSN 0346-251X.

Slavonic Pedagogical Studies Journal, ISSN 1339-866o, Volume 5 Issue 2, September 2016 
OXFORD, R. 1990. Language learning strategies: What every teacher should know. New York: Newbury House. ISBN 9780066326078.

REID, E. 2014. Challenges of Teaching English to Gifted Children. In: Hradec Králové Journal of Anglophone Studies. vol. 2. n. 1, pp. 104-113. ISSN 23363347.

RENZULLI, J. S. 2011. What makes giftedness? Re-examining a definition. In: Phi Delta Kappan, vol. 92, n. 8, p. pp. 81-88. ISSN 1940-6487.

RUBIN, J. 1975. What the "good language learner "can teach us. TESOL Quarterly, vol. 9, pp. 41-51. ISSN 1545-7249.

SILVERMAN, L. 2012. Giftedness 101. New York: Springer Publishing Company. ISBN 9780826107978.

VESELÁ, K. 2010. Role of Creative Writing in Foreign Language Teaching = Úloha kreatívneho písania vo vyučovaní cudzieho jazyka In. Cizojazyčná výuka a nadaný žák : Foreign language teaching and gifted and talented pupil. Brno : Masarykova univerzita. ISBN 978-80-210-5375-5, pp. 184-194.

VLČKOVÁ, K. - PŘIKRYLOVÁ, J. 2011. Strategie učení se cizímu jazyku. Dotazník pro žáky. Praha: Národní ústav odborného vzdělávání. ISBN 97880-87652-37-4.

VÚDPaP-Výskumný ústav detskej psychológie a patopsychológie. 2009. Vzdelávacie programy pre žiakov so všeobecným intelektovým nadaním. Available online: http://www.vudpap.sk/informacie-pre-pedagogov/.

„This work was supported by the Slovak Research and Development Agency under the contract No. APVV-15-0368 Prax v centre odborovej didaktiky, odborová didaktika v Centre praktickej prípravy."

doc. PhDr. Božena Horváthová, PhD.

Constantine the Philosopher University in Nitra

Faculty of Education

Department of Language Pedagogy and Intercultural Studies

Drážovská 4, 94974 Nitra,

Slovakia

bhorvathova@ukf.sk

Mgr. Eva Reid, PhD.

Constantine the Philosopher University in Nitra

Faculty of Education

Department of Language Pedagogy and Intercultural Studies

Drážovská 4, 94974 Nitra,

Slovakia

ereid@ukf.sk 